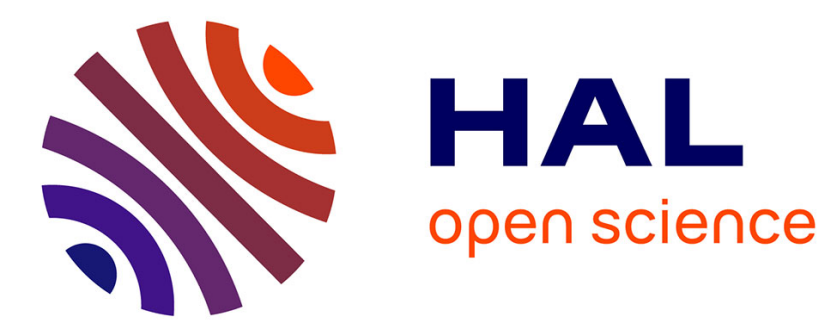

\title{
Converting a successful research project into a sustainable service: the case of the SoDa web service
}

Benoît Gschwind, Lionel Ménard, Michel Albuisson, Lucien Wald

\section{To cite this version:}

Benoît Gschwind, Lionel Ménard, Michel Albuisson, Lucien Wald. Converting a successful research project into a sustainable service: the case of the SoDa web service. Environmental Modelling and Software, 2006, 21, pp.1555-1561. 10.1016/j.envsoft.2006.05.002 . hal-00361357

\section{HAL Id: hal-00361357 \\ https://hal.science/hal-00361357}

Submitted on 13 Feb 2009

HAL is a multi-disciplinary open access archive for the deposit and dissemination of scientific research documents, whether they are published or not. The documents may come from teaching and research institutions in France or abroad, or from public or private research centers.
L'archive ouverte pluridisciplinaire HAL, est destinée au dépôt et à la diffusion de documents scientifiques de niveau recherche, publiés ou non, émanant des établissements d'enseignement et de recherche français ou étrangers, des laboratoires publics ou privés. 


\title{
Converting a successful research project into a sustainable service: the case of the SoDa web service
}

\author{
Benoît Gschwind, Lionel Ménard, Michel Albuisson and Lucien Wald \\ Centre Energétique et Procédés, Ecole des Mines de Paris / Armines, BP 207, 06904 Sophia Antipolis \\ cedex, France. E-mail: lionel.menard@ensmp.fr
}

Information on solar radiation is a critical issue in several environmental domains. The means for accessing information suffer from severe drawbacks. The SoDa project was launched (2000-2003, IST programme of the European Commission) to bring solutions by an efficient use of information and communication technologies. Integration of information sources of different natures was realized by the SoDa Intelligent System. Surveys of users demonstrated that large gains in terms of efficiency, costs, etc. were expected by engineers, companies, agencies and research institutes. The SoDa Service was created in 2003. During the past three years, it has undergone several improvements, including works on the user interface and on the presentation of the services, all aiming at consolidating it with respect to access by users. Promotion efforts were made in the media, including TV. The use of the SoDa Service is increasing from year to year: in 2003, 10000 requests were satisfied, in 2004, 17000 requests and 27000 in 2005. This article presents the lessons learned from the past years and the perspectives of the SoDa Service. We discuss the sustainability of the SoDa Service, the technologies used and the approach to customers, in the perspective of building a B2B merchant site.

Keywords:

Solar radiation, renewable energies, environment, satellite, interoperability, web services, XML, customers, smart network, market

\section{Introduction}

Information on solar radiation is a critical issue in several environmental domains as well as for energy production by means of solar-powered systems. Well-controlled measurements of radiation are available in a limited number of sites. Outside these sites, models are applied to infer the radiation from these data. The results are usually not satisfactory and there is a large discrepancy between user request and available information (Cros et al. 2004). Large gains in terms of efficiency, costs, etc. would be attained by engineers, companies, agencies and research institutes if relevant information 
Gschwind B., Ménard L., Albuisson M., Wald L., Converting a successful research project into a sustainable service: the case of the SoDa Web service. Environmental Modelling and Software, 21, 1555-1561, 2006, doi:10.1016/j.envsoft.2006.05.002.

were more easily available for virtually any geographical location at any time (Bourges and Kadi 1995). This can be done by the means of image processing techniques for extracting solar radiation information from Earth observation satellite images (Rigollier et al. 2004; Mueller et al. 2004). Several databases are now available on the Internet (Fontoynont et al. 1998; Lefèvre et al. 2003) or in CDs (ESRA 2000; Remund et al. 2003).

However, these efforts are not sufficient. The project SoDa used the considerable previous experience gained by its consortium as a springboard to answer users needs by an efficient use of advanced information and communication technologies. It was sponsored by the IST programme (Information Society Technology) of the European Commission from January 2000 to March 2003. Three major problems were identified to supply users with information relevant to their requests (Cros et al. 2004): improved access to information, improved description and knowledge in space and time of the radiation field and related quantities, improved matching to actual needs. Several information sources of different natures were integrated within a smart network on the web (http://www.sodais.com) to solve these problems. The sources include databases containing solar radiation parameters, including those originating from an advanced processing of satellite images, and other relevant information. They also include user-oriented applications. Several domains are under concern: environment, vegetation, climate change, oceanography, health, energy-conscious building design, renewable energies, daylighting and material ageing and weathering.

The SoDa Service represents a large improvement in access by users to information in solar radiation. Having a common access point makes it easier to users who do not have to remember and store several URLs (one stop shop). The standardization of the interfaces querying the space and time attributes of a request and the adoption of standards for describing these attributes make the uptake by users easier. The standardization of the outputs is a major improvement compared to efforts made in coping with various formats. The chaining of proven applications within the network offers the most accurate way to information and answers needs beyond measurement. This is enforced by the networking capabilities of the SoDa Service. Since any provider can easily declare an application, the SoDa Service is capable of shifting from one application to a more appropriate one and consequently is capable of offering the best service available. Another innovation is to supply users with information of high quality. High quality means improved matching to actual needs: the supplied information answers needs better than raw observed data would. In addition time-space coverage and improved time-space sampling are improved. The SoDa prototype was gauged by users as discussed later. Given their high expectations, an operational SoDa Service was set up in January 2003 and has been operated since then. 
Gschwind B., Ménard L., Albuisson M., Wald L., Converting a successful research project into a sustainable service: the case of the SoDa Web service. Environmental Modelling and Software, 21, 1555-1561, 2006, doi:10.1016/j.envsoft.2006.05.002.

This article presents the lessons learned from these past years in converting a successful research project into a sustainable Web service. The technologies used are presented briefly; they are the subject of previous publications (Gschwind et al. 2005; Wald et al. 2002). Users were instrumental in the project SoDa and their role is described. Then the approach to customers is discussed in the perspective of a B2B merchant site.

\section{The SoDa Intelligent System}

The SoDa Intelligent System (SoDa IS) is a set of pieces of software that is central to the SoDa Service (Wald et al. 2002). It performs the integration and exploitation of diverse networked information sources (also called services) that are geographically dispersed. It offers a common access point implemented as an Internet server. The SoDa IS is flexible and has demonstrated its capabilities in integrating services provided by non-members of the SoDa project. In that sense, the SoDa Service and its Intelligent System can be seen as an efficient means to valorize scientific expertise and to perform transfer of knowledge from researchers to practitioners.

Like several other projects where interoperability is at stake, the SoDa IS relies upon available and reliable data exchange protocols and on systems to guide, connect, and transfer data across computer networks (Bianconi et al. 2004; Denzer et al. 2005; Smiatek 2005). XML is a convenient way to exchange information between services (Denzer et al. 2005; Kokkonen et al. 2003). An XML scheme was defined and is used for all exchanges in the SoDa IS (Wald et al. 2002). Services are described by a Service Descriptor, written in XML. The use of the XML in the SoDa project is a definite advantage with respect to the adoption of the SoDa Service by providers for publishing their databases and applications. They do not have to change their own format; a simple cgi script converts the SoDa XML into the metadata used by the service provider.

The SoDa IS has several functionalities that are detailed in Gschwind et al. (2005). One of them is to thematically organize the available services (databases and applications) and subsequently provides a means to dynamically discover the contents of the SoDa Service. This functionality was abandoned in 2005 under the influence of users as discussed later. Once a service is invoked by the user (Figure 1), the SoDa IS reads a XML file called the Service Descriptor. This file contains metatags describing the content of the Graphical User Interface (GUI) that is specific to each service. The GUI is dynamically constructed. The user fills in the requested parameters and then executes it. Results are formatted by the SoDa IS and presented to the user. 


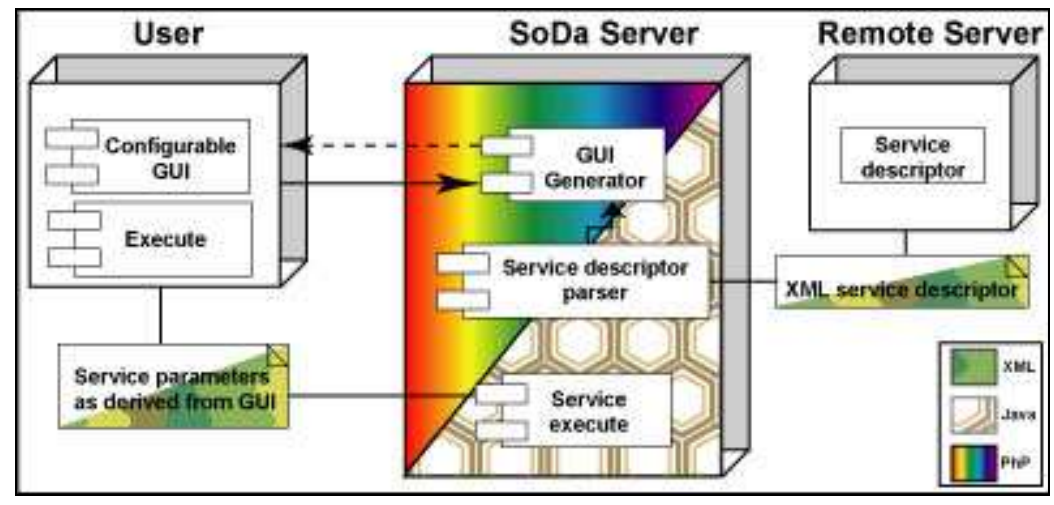

Figure 1. SoDa Service invocation, as of 2005

\section{The role of users in the SoDa project}

The SoDa project was user-driven. The participation of users helped in designing the SoDa IS and the SoDa Service, improving them, assessing their value, assessing the market and disseminating the outcomes of the project. Considerable previous experience was available on the user needs in solar radiation for multiple usage. It was based on the outcomes of several international and national projects (Asimakopoulos et al., 1995; Bourges and Kadi, 1995; Brösamle et al., 2001; CIBSE, 2004; Cracknell et al., 2001; Cros et al., 2004; Durand et al., 1999; Fisher and Flemming, 1999; Heliosat-3, 2001; Lorenz et al., 2004; Fontoynont et al., 1998; Scherrer, 1992). The project SoDa consulted approximately 100 users thus contributing to this experience (Heinemann, 2000; iCons, 2001).

Beside the environmental domains, users were shared in three categories: companies, consultants and researchers, agencies, since their approach to and use of data / services are different. User requirements vary with domains and categories but common features can be found. They may be subdivided into two sections:

- general requirements, i.e. the requirements expressed by the large majority of the users and, therefore, to be considered as high-priority requirements,

- $\quad$ specific requirements, i.e. requirements expressed per application breakdown. Some of them are reported in the general requirements as well, others are specific to a sector and were considered as mid-priority requirements.

High-priority requirements are on the one hand on data, and especially on time series of long duration (several years) of radiation data (hourly, daily, monthly). This information should be available for any site in the world preferably. Simultaneous information on air temperature is sometimes requested. On the other hand, functional specifications were made. Information requested 
Gschwind B., Ménard L., Albuisson M., Wald L., Converting a successful research project into a sustainable service: the case of the SoDa Web service. Environmental Modelling and Software, 21, 1555-1561, 2006, doi:10.1016/j.envsoft.2006.05.002.

is most often located in space and time. The users' comments on time and space requirements suggested that the SoDa IS should take care of these parameters instead of the providers of the applications. This was a strong concept that shapes the SoDa IS. This leads to a harmonization in interfaces that in turn, ensures a better identification of the SoDa Service (Fig. 2).

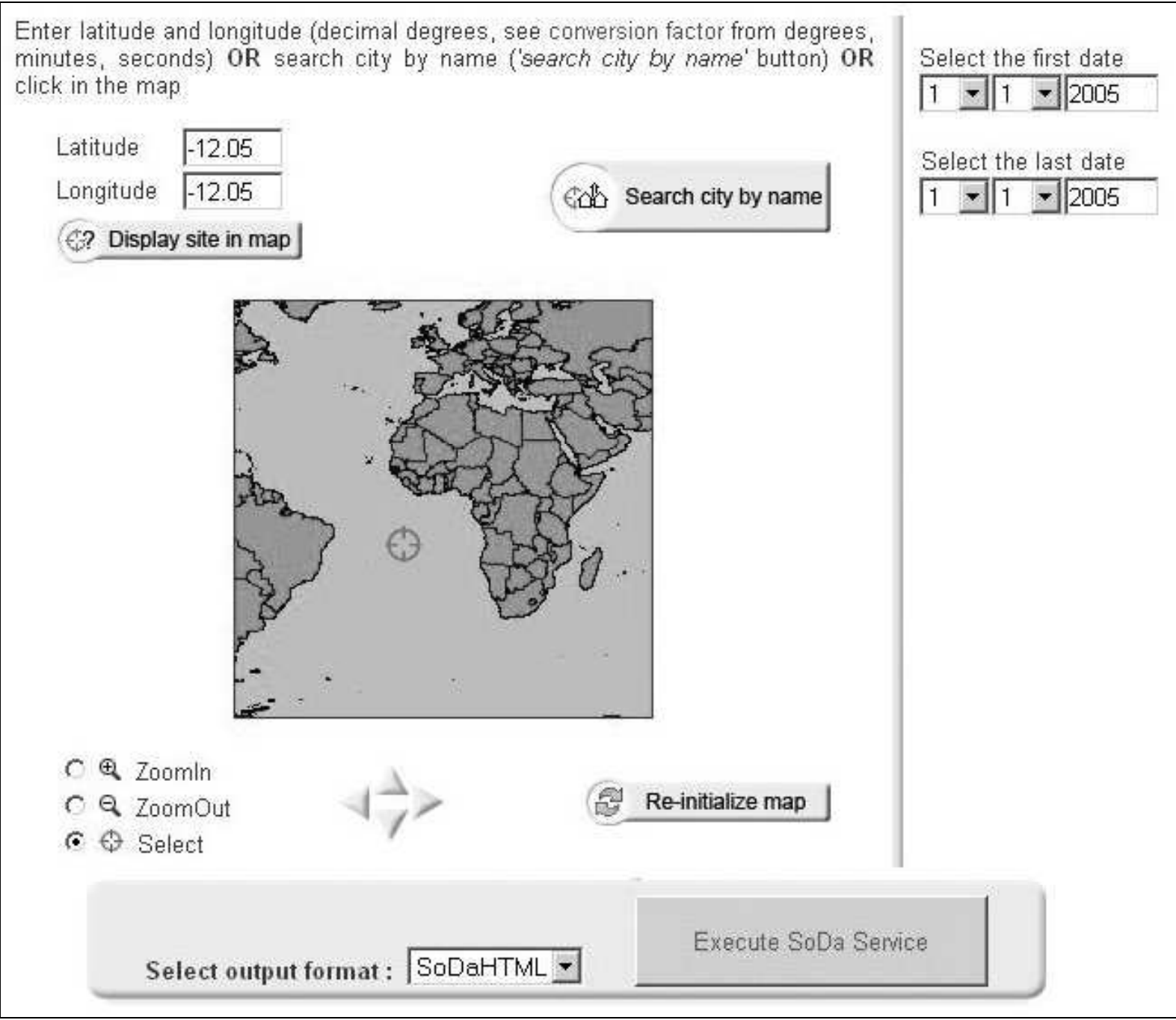

Figure 2. Example of a GUI constructed by the SoDa IS, as of 2005. The GeoSearch tool is displayed on left, the TimeSearch tool on right.

The GeoSearch tool allows the selection of a site by geographical co-ordinates (latitude and longitude) or through map clicking. All users agree that a step of $1 \mathrm{~km}$, or equivalently 0.01 degree, is appropriate for the selection process. A small number of users ask for a sexagesimal system, but all users agree (i.e. do not oppose) for a decimal system that is easier to manage. The geographic limits bounding a resource are given by the provider of the resource through the Service Descriptor; they 
Gschwind B., Ménard L., Albuisson M., Wald L., Converting a successful research project into a sustainable service: the case of the SoDa Web service. Environmental Modelling and Software, 21, 1555-1561, 2006, doi:10.1016/j.envsoft.2006.05.002.

define the map to be displayed in the GUI. The TimeSearch tool allows the selection of an instant or a period. Time boundaries are given by the Service Descriptor. Several time systems exist: legal time, universal time coordinated (UTC) and true solar time. The TimeSearch tool should use these systems, as ordered by the provider of the resource. However, legal time is excluded. The use of daylight saving time is not recommended, as countries have set different dates for this change to legal time and it is not possible to fix a date valid for all years and all countries. Users agree with this view. Those working with hourly values have adopted the UTC, mean solar time or true solar time.

Other issues were addressed. A growing number of users questions the accuracy of data and applications. The situation can be summarized as "better a low-accuracy than no information at all". There are many elements in accuracy and the users do not target them precisely. Providers of resources should deliver accuracy parameters, such as bias, root square mean error, or more global quality parameters. There are few demands on near real-time access to radiation data (management of solar-powered systems, prevention of health diseases in summer). Agriculture allows a few days lag between the last day of the decade or week and the availability of the information. As for the delay in delivery of available data, users clearly prefer instant delivery.

Three prototypes of the SoDa Service were built during the project. There were definite advantages in iterative prototyping for the team and users. Indeed, we recommend to exploit such approach as it creates a better acceptance of the outcomes of the project by users. The advantages for the developing team are:

- better proximity to users and more interactions;

- better understanding of their needs;

- more focused specifications and changes;

- modular programming and re-use of components;

- gain in efficiency and time;

- better understanding of the changes in the point of view of users as it evolves with changes in prototype.

For the users, advantages are:

- get acquainted to new tools progressively with a smooth learning curve;

- discover new opportunities in business or others;

- propose more focused specifications;

- propose services tailored to needs and opportunities.

All prototypes were gauged by several tens of users who thus contributed to the re-engineering of each prototype. As a whole, users expressed satisfaction. The surveys show that several benefits are 
Gschwind B., Ménard L., Albuisson M., Wald L., Converting a successful research project into a sustainable service: the case of the SoDa Web service. Environmental Modelling and Software, 21, 1555-1561, 2006, doi:10.1016/j.envsoft.2006.05.002.

expected in all areas where solar radiation makes significant impacts. Close to the end of the SoDa project, a consultation of users was made through on-line questionnaires (70 returns) and a users workshop was held in Paris in November 2002, gathering 20 selected users, and representing a wide panel of professionals in solar radiation. The outcomes of these consultations and workshop praised the usefulness of such a service, its potential for filling in users' expectations, the overall quality of the information delivered and the recognition for the high degree of expertise held by the SoDa project consortium. Users said that the SoDa Service was an efficient means for transferring highly specialized knowledge from researchers to practitioners and encouraged the transformation of the prototype into a sustainable SoDa Service. However, users clearly stated a lack of visibility for this consortium that may in the future impede the sustainability of the exploitation of the SoDa Service, a lack of actions for promoting the SoDa Service, and on a more technical ground, a difficulty in finding appropriate applications in the 2002 prototype of the SoDa Service.

The market aspects were also covered. The question "are you ready to pay for data and other information" divided users according to the domain of activity: when this domain may be profitable for companies, they are ready to pay. Companies are more inclined to purchase information than public administrations or research organizations. Besides the sales of information available in the SoDa Service, there was a clear demand for consultancy and training. The basic data were expected to be given for free, following the example of the meteorological data in the USA and contrary to the current procedures in Europe. In any case, users underlined that selling information required a clear identification of the vendor that should be known, capable and reliable, and a clear identification of the benefits brought by the SoDa Service compared to current practices.

\section{Converting SoDa project outcomes into the SoDa Service}

In view of these outcomes, the SoDa project consortium decided to operate the SoDa Service on a selffunded basis during one, then two years. The SoDa Service is gradually recognized by professionals and its effective use is increasing. In 2003, 10000 requests to services were satisfied. A request is an access to a set of data or the execution of an application. There was 17000 satisfied requests in 2004 and 27000 in 2005 (Fig. 3). The market analysis made during the SoDa project by the Italian company iCons showed that a market niche exists for such a service. Nevertheless, the market was not ready. Accordingly, the SoDa Service was run on a free-access basis in order to increase its visibility and gain experience in running an operational service and exploring market opportunities. 


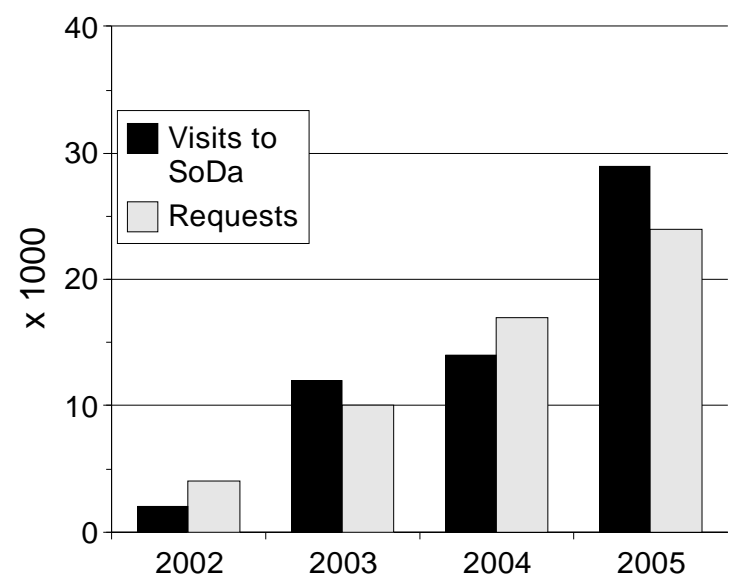

Figure 3. Number of visits to the SoDa Service and number of requests per year (in thousands)

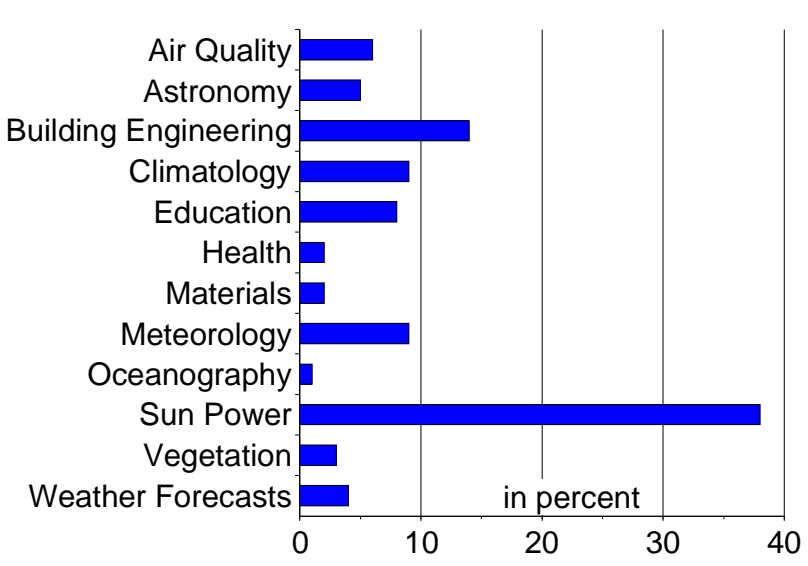

Figure 4. Relative importance of the domains of usage of the SoDa Service, in percentage.

In 2003, Ecole des Mines de Paris / Armines (EMP) decided to take full leadership of the exploitation of the SoDa Service because we strongly believed in its usefulness and in the smart technologies sustaining the SoDa IS. While the other partners agreed to maintain their applications, we (EMP) undertook several activities to develop the SoDa Service. The conversion of the third and last prototype into a sustainable service was not an easy task. It involves several different aspects: technology, marketing, and promotion, with impacts on several of the initial concepts of the SoDa prototype.

The activity in 2003 was to transfer the SoDa IS from its creators (Joint Research Center JRC-Ispra) to our premises. The SoDa IS was mostly written in Java (servlets and applets). This implied training for our team, who was not well conversant in Java. In Summer 2003, the operational SoDa Service became that of EMP and that of Ispra was shut down. Prior to improvements, a model of the SoDa IS was built in 2004 in UML (Universal Modeling Language) to better focus changes in software.

The SoDa IS was formerly built-up using Java technology both on the server side with servlets and on the client side with applets. The description of the content of the SoDa Service catalogue was made in XML. The choice of these languages was inherited from the European project; it was guided by the knowledge of these languages by the JRC, in charge of the technology development, and the re-use of proven pieces of software, such as HGS (Wald et al. 2002). Servlets and XML are totally hidden to the users but applets are loaded in the client browser. At that time, users' feedbacks clearly showed that Java applets were posing a problem to many of them: for various reasons, they did not have the capability of installing Java Runtime Environment (JRE) on their own PC. Consequently, a significant 
Gschwind B., Ménard L., Albuisson M., Wald L., Converting a successful research project into a sustainable service: the case of the SoDa Web service. Environmental Modelling and Software, 21, 1555-1561, 2006, doi:10.1016/j.envsoft.2006.05.002.

number of potential users were unable to launch applications in the SoDa Service. The SoDa Service used applets for the GUI that displays maps for geographical selection of site of interest and queries parameters to be input to the remote application. It is therefore a crucial point in the invocation in any service offered by the SoDa Service. Errors occurring at that stage have a strong negative impact on the perception by users of the SoDa Service. In Summer 2005, all Java applets were removed and replaced either by HTML code for the Service Discovery or by a PHP code for building the GUI. The initial concept of dynamic discovery of services was abandoned; this was not harmful since after reengineering as mentioned below, the catalog remains stable.

Additional work was performed on the GUI at users request; in particular, the selection of a geographical site by the means of a gazetteer was made possible.

Beside these technical changes, a strategic reflection was conducted on the future of the SoDa Service. We had to switch from a prototype service, providing access to a wide range of domains, to a professional one, not covering all domains and addressing preferably the most active users in solar radiation as indicated in Figure 4. These selected domains are believed to offer potential development for marketing the SoDa Service. A strategic plan was set up, which guided the whole process of redesigning the SoDa Service in view of attracting professionals. These users should be able to find the right information in seconds and should not be wandering in a fuzzy and complex structure gathering heteroclite services as it was before 2005. The catalogue of services was re-designed; it was previously ordered by type of information: data, advanced parameters and user-oriented applications. The new catalogue is now ordered by domains, e.g., air quality, meteorology, solar energy systems, etc. (Figure 4). In addition, help and examples of resulting products were developed. Simple yet efficient folders and menus, reflecting this domain-driven approach, were developed; new items were added, such as FAQ, Help, Cases Studies and Examples, moving from a research project Web site to a clear, wellstructured and professional one. Finally, the entire Web site, originally in English, was also translated into French.

Actions were made toward medias in order to promote the use of information on solar radiation and accordingly the SoDa Service. The company Gedeon, from Paris, made several stories for TV for adult and children audiences. These stories display several cases studies showing real usage of the SoDa Service. The story about skin cancer highlights how the SoDa Service enables oncologists to know the exact level of their patients' exposure to natural UV. Two stories show that the SoDa Service helps architects to size the number of solar panels that any particular European house would need to produce electricity to cover domestic needs. The last one about air quality describes how the SoDa Service is used by meteorologists to better know the intensity of radiation, enabling a better forecast of ozone 
Gschwind B., Ménard L., Albuisson M., Wald L., Converting a successful research project into a sustainable service: the case of the SoDa Web service. Environmental Modelling and Software, 21, 1555-1561, 2006, doi:10.1016/j.envsoft.2006.05.002.

levels in cities. These stories were broadcasted in the Eurovision network, gathering publicly owned broadcast companies in Europe. Excerpts of the stories are available at Youris.com, a video Web portal for the IST program. Stories were also published in specialized magazines. Two interviews were conducted from radio broadcasters.

Referencing the SoDa Web site to major search engines and portals was a time consuming effort. Currently more than 37 different search engines including Google, Inktomy-Slurp (Yahoo.com), MSNBot (Microsoft), WISENutbot (Looksmart), Ask Jeeves, Alta-Vista, AOL, regularly browse, extract and classify SoDa Web documents. In addition, we continuously monitor accesses to the SoDa Service (Figure 1).

The audience was surveyed by the means of an on-line questionnaire (159 answers) in January 2005. Twenty-five per cent (25\%) of the users are companies. Consultants and private R\&D account for $50 \%$ (called others hereafter). Public administrations account for $6 \%$ and public research for $19 \%$. Eighty percent of users are located in Europe. Figure 4 reports on the relative importance of the domains of usage. The most represented domain is the production of energy by means of sun-powered systems by far $(38 \%)$ followed by building engineering (14\%). Meteorology, climatology and education account for $9 \%$ each. Two-thirds of the companies (66\%) and others (65\%) are working in sun-powered systems. One-third of the companies (29\%) and one-fifth of the others $(21 \%)$ are working in building engineering.

In January 2005, we subscribed to the Google Adsense program, which is a fast and easy way for Web site publishers to display relevant Google ads on content pages of their Web site and earn money. The ads that show-up on the SoDa Web site generate small yet regular incomes. As they are based on the content of the Web site, they really cope with the domains covered by the SoDa Service. Beside the fact that these ads give a more professional look to the Web site, they also help the SoDa Service to be identified by the targeted Web site as an actor in the solar radiation market, thanks to the referrer mechanism in logs files.

\section{Lessons learned and current developments}

There are several lessons to be learnt from these past three years in various domains: technology, user key role, cost of investment and business model. Technology was already discussed. We learnt that it may be counter-productive to use too advanced tools from the client side. Centralizing essential components on the server side guarantees a better control and efficiency of the service. 
Gschwind B., Ménard L., Albuisson M., Wald L., Converting a successful research project into a sustainable service: the case of the SoDa Web service. Environmental Modelling and Software, 21, 1555-1561, 2006, doi:10.1016/j.envsoft.2006.05.002.

Although users were in a key position in the SoDa project, they were at that stage perceived as contributors to the technological development. We did not consider how the whole SoDa Service could serve them to develop their business, but we were more focused on providing them very accurate services that they can use. This led us to develop a complex and "scientific oriented" catalogue of services. A long and difficult reflection process enriched by interviews of users and a better listening to their concerns permitted a move towards a catalogue that is based on domains of activity of users, with partial redundancy in services. The major goal of this approach was to increase the use of the SoDa Service by professionals and at a further stage, to be able to convert users into potential customers.

Soon after the operations began, it became obvious that the Web site of the project was focusing too much on the availability of the services and that, even re-engineered, it was not supporting a customer approach. The change from "services-approach" to "domain-approach" enabled the building of a richer Web site containing several documents that are linked to a domain and help users in exploiting the SoDa Service.

This three-years period of self-funded activities for improving the SoDa Service required a consequent amount of efforts. We estimate that each year an average of four person-month was spent, including senior and junior engineers and students. In order to sustain our commitment to the SoDa Service, the Service itself should generate incomes that will partly support these technological efforts.

In the course of the SoDa project, the Italian company iCons analyzed several scenarios for development and sustainability in 2002. Based on 10 real case studies, four scenarios were clearly detailed:

- "Free for All", where the entire offer is available for free with no restriction;

- "Limited for Free", where all data and services are available for free but all, or several, with restrictions: registration, membership or sponsors... or limitations as for the rules of access, the usage of data etc.;

- "Mixed Free and Pay", where free and on-payment services are offered through a variety of modalities, often depending on quality, updating and formats of data;

- "Pay", where the offer is uniquely on payment.

The study showed that the best solution for the SoDa Service was the "Mixed Free and Pay" formula. It better suits the expectations of users as they are available to pay only for value-added services (tailored, customized information, targeted services, consulting and training). Although available in 
Gschwind B., Ménard L., Albuisson M., Wald L., Converting a successful research project into a sustainable service: the case of the SoDa Web service. Environmental Modelling and Software, 21, 1555-1561, 2006, doi:10.1016/j.envsoft.2006.05.002.

principle, the actual willingness to pay is conditional upon the recognition of a real differentiation between the free and pay services available in the SoDa Service.

We are currently setting-up an e-commerce Web site that will host a mix of free and pay services. In order to demonstrate the pay services, actual examples of results will be shown or several of these services will be partly accessed for free. A prototype was developed using a e-commerce platform and is currently being tested. The nesting of the SoDa IS inside an e-commerce platform was successfully realized. As e-commerce is not the core of our activities, we are still working on the economic and legal aspects relating to e-commerce and are looking for external partnership. We expect to be ready to launch the e-commerce Web by mid 2006.

\section{Conclusions}

EMP is participating in many projects funded by the European Commission and is well aware of others. Only a very few projects lead to sustainable services. The SoDa Service is an example that still needs to be confirmed. The valorization of research and technological development into sustainable services is very demanding. It requests efforts in various aspects: technology, business development, marketing, and communication. Only a very few research institutes are equipped to undertake such efforts and that may explain why successful projects are rarely producing sustainable services. Such efforts were made by EMP not because of the economic potentials but because we believe that the SoDa Service is a strategic asset for the development of research on solar radiation at EMP.

\section{References}

Asimakopoulos, D., Carvalho, L., Chauvel, P., Czeplak, G., Dumortier, D., Fontoynont, M., Kittler, R., Littlefair, P., Page, J., Perraudeau, M., Petrakis, M., Tregenza, P., 1995. Availability of daylight in Europe and design of a daylighting atlas. Final Report, European Commission, JOU2 CT92-0144, 1995.

Bianconi, R., Galmarini, S., Bellasio, R., 2004. Web-based system for decision support in case of emergency: ensemble modelling of long-range atmospheric dispersion of radionuclides. Environmental Modelling \& Software 19, 401-411. doi: 10.1016/S1364-8152(03)00139-7.

Bourges, B., Kadi, L., 1995. European Solar Radiation Atlas: User needs and specifications. A report to the European Commission, Contract JOU2-CT94-0305, EMN/ESRA/Doc 6.95, Ecole des Mines de Nantes, Nantes, France, 95 p.

Brösamle, H., Mannstein, H., Schillings, C., Trieb, F., 2001. Assessment of solar electricity potentials in North Africa based on satellite data and a geographic information system. Solar Energy 70, 1-12. 
Gschwind B., Ménard L., Albuisson M., Wald L., Converting a successful research project into a sustainable service: the case of the SoDa Web service. Environmental Modelling and Software, 21, 1555-1561, 2006, doi:10.1016/j.envsoft.2006.05.002.

CIBSE, 2004. Guide F: Energy efficiency in buildings. Chartered Institution of Building Services Engineers, London, United Kingdom, 204 p.

Cracknell, A. P., Newcombe, S. K., Balck, A. F., Kirby, N. E., 2001. The ABDMAP (algal bloom detection, monitoring and prediction) concerted action. International Journal of Remote Sensing 22, 205-247.

Cros, S., Mayer, D., Wald, L., 2004. The availability of irradiation data. Report IEA-PVPS T2-04: 2004, International Energy Agency, Wien, Austria, 29 p.

Denzer, R., Riparbelli, C., Villa, M., Güttler, R., 2005. GIMMI: geographic information and mathematical models inter-operability. Environmental Modelling \& Software 20, 1478-1485. doi: 10.1016/j.envsoft.2004.07.018.

Durand, D., Sandven, S., Cauneau, F., Wald, L., 1999. Characterisation of inland and coastal waters with space sensors. Report to the European Commission JRC, Contract 14049-1998-06 F1PC ISP NO, prepared by Nansen Environmental and Remote Sensing Center (Norway) and Armines (France), 220 p.

Fisher, J., Flemming, N., 1999. Operational Oceanography: Data Requirements Survey. EuroGOOS Publication \#12, Southampton Oceanography Centre, Southampton, UK, 59 pp., ISBN 0-904175-36-7.

ESRA, 2000. European Solar Radiation Atlas, Fourth edition, includ. CD-ROM. Edited by J. Greif, K. Scharmer. Published for the Commission of the European Communities by Presses de l'Ecole, Ecole des Mines de Paris, Paris, France.

Fontoynont, M., Dumortier, D., Heinemann, D., Hammer, A., Olseth, J., Skartveit, A., Ineichen, P., Reise, C., Page, J., Roche, L., Beyer, H.-G., Wald, L., 1998. Satellight: a WWW server which provides high quality daylight and solar radiation data for Western and Central Europe. In Proceedings of the 9th Conference on Satellite Meteorology and Oceanography. Published by Eumetsat, Darmstadt, Germany, EUM P 22, pp. 434435.

Gschwind, B., Ménard, L., Albuisson, M., Wald, L., 2005. Three years of experience with the SoDa web service delivering solar radiation information: lessons learned and perspectives. In Proceedings of the 19th International Conference on Informatics for Environmental Protection, J. Hrebicek, J. Racek Eds, Part 1, pp. 95-102. Published by the Masaryk University in Brno, Czech Republic.

Heinemann, D., 2000. Inventory of information sources. Report to the European Commission, Project SoDa, IST-1999-12245, University of Oldenburg, Oldenburg, Germany, November 2000, 17 p.

Heliosat-3, 2001. Compilation of data requirements. Report to the European Commission, Project Heliosat-3 NNE5-2000-00413, University of Oldenburg, Oldenburg, Germany, June 2001, 14 p.

ICons, 2001. User Requirements. Report to the European Commission, Project SoDa, IST-1999-12245, iCons, Lodi, Italy, October 2001, 28 p.

Kokkonen, T., Jolma, A., Koivusalo, H., 2005. Interfacing environmental simulation models and databases using XML. Environmental Modelling \& Software 18, 463-471. doi:10.1016/S1364-8152(03)00020-3. 
Gschwind B., Ménard L., Albuisson M., Wald L., Converting a successful research project into a sustainable service: the case of the SoDa Web service. Environmental Modelling and Software, 21, 1555-1561, 2006, doi:10.1016/j.envsoft.2006.05.002.

Lefèvre, M., Cros, S., Albuisson, M., Wald, L., 2003. Developing a database using Meteosat data for the delivery of solar radiation assessments at ground level. In Proceedings of the 23rd EARSeL Annual Symposium "Remote Sensing in Transition", Rudi Goossens editor, Milpress, Rotterdam, Netherlands, pp. 485-489.

Lorenz, E., Betcke, J., Drews, A., Heinemann, D., Toggweiler, P., Stettler, S., van Sark, W., Heilscher, G., Schneider, M., Wiemken, E., Heydenreich, W., Beyer, H. G., 2004. PVSAT-2: intelligent performance check of PV system operation based on satellite data. In Proceedings of the 19th European Photovolatic Solar Energy Conference \& Exhibition, Paris, France, 7-11 June 2004.

Remund, J., Kunz, S., Lang, R., 2003. MeteoNorm. includ. CD-ROM, Fifth ed. Meteotest, Bern, Switzerland.

Mueller, R.W., Dagestad, K.F., Ineichen, P., Schroedter, M., Cros, S., Dumortier, D., Kuhlemann, R., Olseth, J.A., Piernavieja, G., Reise, C., Wald, L., Heinnemann, D., 2004. Rethinking satellite based solar irradiance modelling - The SOLIS clear sky module. Remote Sensing of Environment, 91, 160-174.

Rigollier, C., Lefèvre, M., Wald, L., 2004. The method Heliosat-2 for deriving shortwave solar radiation from satellite images. Solar Energy, 77(2), 159-169.

Scherrer, R., 1992. Neukonzeption Meteonorm - Bedürnisanalyse. Internal report (in German), Meteotest, Bern, Switzerland.

Smiatek, G., 2005. SOAP-based web services in GIS/RDBMS environment. Environmental Modelling \& Software 20, 775-782. doi: 10.1016/j.envsoft.2004.04.008.

Wald, L., Albuisson, M., Best, C., Delamare, C., Dumortier, D., Gaboardi, E., Hammer, A., Heinemann, D., Kift, R., Kunz, S., Lefèvre, M., Leroy, S., Martinoli, M., Ménard, L., Page, J., Prager, T., Ratto, C., Reise, C., Remund, J., Rimoczi-Paal, A., Van der Goot, E., Vanroy, F., Webb, A., 2002. SoDa: a project for the integration and exploitation of networked solar radiation databases. In: Environmental Communication in the Information Society, W. Pillmann, K. Tochtermann Eds, Part 2, pp. 713-720. Published by the International Society for Environmental Protection, Vienna, Austria. 